\title{
Are rice seedlings affected by changes in water quality caused by crayfish?
}

\author{
P.M. Anastácio ${ }^{1 *}$, A.M. Correia ${ }^{2}$, J.P. Menino ${ }^{3}$, L. Martins da Silva ${ }^{3}$ \\ 1 IMAR : Institute of Marine Research, c/o Department of Ecology, University of Évora, Rua Romão Ramalho, n59, 7000-671 Évora, Portugal. \\ 2 Universidade de Lisboa, Museu Nacional de História Natural - Museu Bocage (Departamento de Zoologia e Antropologia), Centro de Biologia \\ Ambiental (CBA), Rua da Escola Politécnica 58, 1269-102 Lisboa, Portugal. \\ 3 INIA Estação Agronómica Nacional, Quinta do Marquês, 2784-505 Oeiras, Portugal.
}

\begin{abstract}
Crayfish are considered pests in most wet seeded rice fields, although in some parts of the world, namely in Louisiana (USA), double cropping crayfish and rice can be practiced with success. The direct negative effects of crayfish on rice seedlings are well known, but the indirect effects of crayfish are still unexplored. This paper tests the indirect effects on rice (Oryza sativa) seedlings via modifications in water quality caused by crayfish (Procambarus clarkii) activity. The experiment was performed in open air tanks divided by a mesh which prevented crayfish in the treatment tanks from moving to the other side of the tank. Control tanks were also divided but contained no crayfish. Statistical tests showed that the effects of crayfish on water quality are effectively transmitted across the mesh and into the other side of the tanks. A crayfish density of 1.7 ind. $\mathrm{m}^{-2}$ does affect water quality by increasing turbidity and decreasing dissolved oxygen. Although crayfish changed water quality no statistically significant effects were noted on the final values of: total rice biomass, biomass of not germinated seeds, seedlings biomass, number of not germinated seeds, number of seedlings and seedlings height. We conclude that indirect effects of crayfish on the studied rice variety through water quality changes, are not relevant to early developmental stages.
\end{abstract}

Keywords : Procambarus, turbidity, seedlings, plant-animal interactions, indirect effects.

\section{Introduction}

The red swamp crayfish (Procambarus clarkii, Girard 1852) is a species with proven positive and negative social and economic impacts in most areas where it occurs (Lowery \& Mendes 1977, Grigarick \& Way 1982, Sommer \& Goldman 1983, Grigarick 1984, Huner 1988, Correia 1993, Caño \& Ocete 1994, Caffey 1997). As an example, during 2004 in the « Baixo Mondego » area (Portugal) the « Cooperativa Agricola de Soure » reported economic losses of $43.40 € \mathrm{ha}^{-1}$ of rice production ( $6.3 \%$ decrease in profit) due to the direct effects of crayfish. In places where crayfish are considered a rice field pest, such as Portugal and California, the majority of the rice is wet seeded as oppo-

\footnotetext{
* Corresponding author :

E-mail: anast@uevora.pt
}

sed to e.g. Louisiana where rice fields are flooded after seedling establishment.

The direct effects of crayfish on rice seeds and seedlings, namely uprooting, plant fragmentation (Anastácio et al. 2005) and consumption (Sanguaruang 1988, McClain et al. 1992) are known but they are not the only possible mechanisms of crayfish-rice interactions. Because crayfish are ecosystem engineers through bioturbation (Usio 2000, Usio \& Townsend 2002) other non-trophic indirect mechanisms may be present. Physico-chemical changes in the water and waterlogged soil (e.g. pH, $\mathrm{O}_{2}$, temperature, turbidity, soil structure and composition) may occur (Dean 1969, Rickett 1974, Anastácio \& Marques 1997, Angeler 2001, Rodríguez et al. 2003) therefore modifying the growth and survival of the rice plants. It is known that the number of seeds germinated, and the speed of seed germination increases with an improvement of water

Article available at http://www.limnology-journal.org or http://dx.doi.org/10.1051/limn/2005002 
transparency (Bellido 1991). In previous field studies (Anastácio \& Marques 1997, Anastácio et al. 2000), water within the enclosures was renewed from the outside, which diluted effects of water quality upon rice germination and strongly improved water transparency. Therefore, we hypothesize that field studies in enclosures may have underestimated crayfish effects on rice seedlings and that water quality modifications caused by crayfish may have an impact on seedlings.

Crayfish may increase turbidity (Dean 1969, Rickett 1974, Anastácio \& Marques 1997, Angeler 2001, Rodríguez et al. 2003) and it has been previously suggested that e.g. oligochaete worms may interfere with rice seedling establishment by increasing turbidity (Stevens \& Warren 2000). In addition increased turbidity may decrease the efficiency of some chemicals commonly added to rice fields (Poovey \& Getsinger 2002). Low dissolved oxygen levels may also affect the normal growth and survival of germinating rice (Kordan in Takahashi 1984, Tinnarelli 1989). The purpose of this paper is to determine to what extent crayfish $(P$. clarkii) presence affect rice field water quality, namely turbidity, dissolved oxygen, $\mathrm{pH}$ and temperature and also to determine if these changes are relevant to rice seedlings.

\section{Methods}

\section{Experimental procedures}

The experiment was performed at the «Estação Agronómica Nacional » (Oeiras, Portugal) in tanks located inside a cage giving protection against unwanted interferences, namely humans or large wild animals. The surrounding area has been used for rice growing during the last 50 years. A natural water source flowing from an open-air reservoir fed by a nearby spring was used. 20 containers of $100 \times 120 \mathrm{~cm}$ bottom area were employed in the experiments. All the tanks were evenly divided in two by a plastic net with a $2 \mathrm{~mm}$ mesh size and a plastic coating in the upper part. This prevented crayfish from changing sides. Ten out of the 20 tanks were stocked with two adult crayfish in one side and the other ten served as controls. This crayfish density $\left(1.7\right.$ adults $\left.\mathrm{m}^{-2}\right)$ is normal for infested rice fields (Correia \& Bandeira in press). The distribution of the treatment and control tanks as well as the side with and without crayfish was randomly assigned. Tanks were filled with $20 \mathrm{~cm}$ of soil and then filled with water to a $5 \mathrm{~cm}$ depth the day before sowing the rice. This is a low depth commonly used by farmers during rice germination. $10 \mathrm{~g}$ of rice seeds of the variety Ariete (the most widely used in Portugal) were pre-soaked for 24 hours and sown in each side of all tanks. Crayfish were captured with dip nets and baited traps 2 weeks prior to the start of the experiment and then kept in containers similar to the ones of the experiment. Crayfish were fed during the acclimatization period and measured (post orbital carapace length - POCL) and weighed (wet weight) just before being placed in the experimental containers. Average crayfish POCL was 33.14 $\mathrm{mm}$, with a minimum of $29.31 \mathrm{~mm}$ and a maximum of $38.73 \mathrm{~mm}$. Average crayfish wet (live) weight was $17.50 \mathrm{~g}$ with a minimum of $12.65 \mathrm{~g}$ and a maximum of $32.47 \mathrm{~g}$. During the experiments the tanks were monitored every 4 days in the morning (approx. 9:00 to 11:00 AM) for water depth, crayfish death or moults and for physico-chemical parameters (temperature, $\mathrm{pH}$, dissolved oxygen, and turbidity). At the end of the experiment, i.e. after 2 weeks, all crayfish were removed. All the rice, including seeds and seedlings, was hand picked. The superficial layer $(\mathrm{ca} .3 \mathrm{~cm}$ ) of the soil was also sieved through a $2 \mathrm{~mm}$ mesh in order to detect hidden items. Laboratory work included careful washing of the rice inside a $2 \mathrm{~mm}$ sieve under a gentle shower in order to remove attached soil fragments, algae or detritus. Germinated rice seedlings were measured in the laboratory to the nearest $\mathrm{mm}$. Dry weight was determined after drying in the oven for $72 \mathrm{~h}$ at $80^{\circ} \mathrm{C}$.

\section{Statistical analysis regarding water quality}

In order to determine crayfish impact on water quality and to check the effects of tank division by a mesh we performed a fixed effects one-way MANOVA with 4 dependent variables and 3 levels in the independent variable. The dependent variables were the average values of : 1) dissolved oxygen, 2) water temperature, 3 ) $\mathrm{pH}$ and 4) turbidity. The levels in the independent variable were: 1) control tanks without crayfish (10 replicates), 2) crayfish on the other side (5 replicates) and 3 ) crayfish on this side (5 replicates). All measurements were independent i.e. in the analysis we did not use water quality measurements from both sides of the same tank. One-way MANOVA was preferred over Repeated Measures or a Split Plot design due to strong criticisms from some authors and difficulties in fulfilling all the assumptions of those designs (Mead et al. 2003, Underwood, pers. com.). A logarithmic transformation, $\log (\mathrm{X}+1)$, was applied to data whenever necessary in order to homogenize variances. The MANOVA was followed by a univariate ANOVA for each dependent variable in order to further explore the causes for the obtained results. Whenever a dependent variable presented significant ANOVA results a post 
hoc Tukey-test was applied to detect differences among treatment levels.

\section{Statistical analysis regarding rice development and survival}

Crayfish directly affect rice seedlings and all the plants and seeds are consumed at the crayfish densities used (Anastácio \& Marques 1997, Anastácio et. al. 2000). Therefore, regarding rice development and survival, we only compared the controls (i.e. tanks without crayfish) and the side without crayfish of the tanks with crayfish. All measurements were independent i.e. in the analysis we did not use measurements from both sides of the same tank. Student's t test was applied on the variables : total rice dry weight, seedlings dry weight, seeds dry weight and seedlings height at the end of the experiment. A Mann-Whitney test was applied to determine differences both on the number of seedlings and of not germinated seeds because these are counts and not measurements (Fowler \& Cohen 1990).
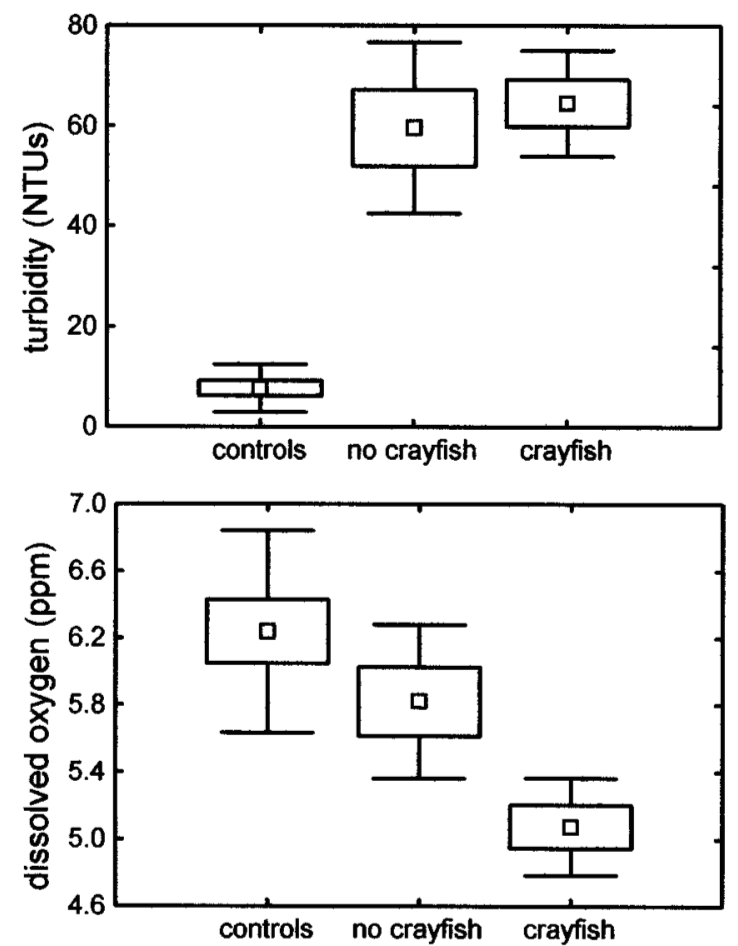

\section{Results}

\section{Effects on water quality}

The MANOVA performed indicates that there are significant differences in water quality (Rao's $\mathrm{R}=8,26166, \mathrm{df} 1=8, \mathrm{df} 2=28, \mathrm{p}<0.001)$ i.e. there are differences among the 3 treatment levels used (controls, side with crayfish and side without crayfish). An ANOVA on each of the factors i.e. turbidity, dissolved oxygen, temperature and $\mathrm{pH}$ (Table 1) showed that turbidity $(\mathrm{p}<0.001)$ and dissolved oxygen $(\mathrm{p}<0.01)$ were strongly affected (fig. 1). Temperature and $\mathrm{pH}$ were

Table 1. Results of the ANOVAs performed for each variable after the MANOVA performed for all the variables together.

\begin{tabular}{lrr}
\hline Factor & $\mathrm{F}$ & \multicolumn{1}{c}{$\mathrm{p}$} \\
\hline Average dissolved oxygen & 8.628 & 0.003 \\
Average pH & 1.824 & 0.192 \\
Average temperature & 1.053 & 0.371 \\
Average turbidity & 56.384 & $<0.001$ \\
\hline
\end{tabular}
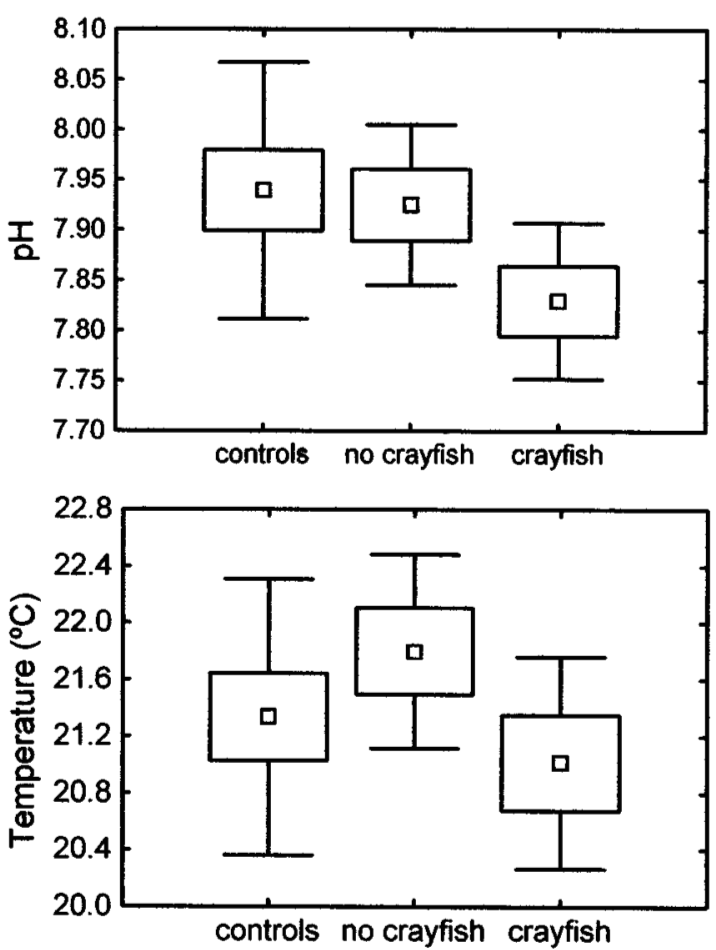

Fig. 1. Box and Whiskers plots of the values of several variables under three different treatment levels. Average, standard error and standard deviation are represented. controls $=$ tanks without crayfish. no crayfish $=$ side without crayfish of the tanks with crayfish. crayfish $=$ side with crayfish of the tanks with crayfish. 
not significantly affected (fig. 1). Average turbidity values were, 7.683, 59.560 and 64.535 NTUs respectively in the control tanks without crayfish, the side without crayfish of the tanks with crayfish and the side with crayfish of the tanks with crayfish. The post-hoc Tukey HSD test performed for the turbidity demonstrated that the control tanks without crayfish differed $(p<0.001)$ from both sides of the tanks with crayfish. Average dissolved oxygen values were 6.237, 5.820 and $5.074 \mathrm{mg} \mathrm{l}^{-1}$ in the control tanks without crayfish, the side without crayfish of the tanks with crayfish and the side with crayfish of the tanks with crayfish. The post-hoc Tukey HSD test performed for the dissolved oxygen showed that the control tanks without crayfish were only significantly different from the « with crayfish $\gg$ side $(\mathrm{p}<0.01)$. Although results were not statistically significant, fig. 1 seems to show a tendency for crayfish to lower water $\mathrm{pH}$.

Some temporal modifications on the water quality were observed during the experiment. Turbidity increased progressively in both sides of the tanks with crayfish (fig. 2) but it was always low in the control tanks. This pattern was not followed by any of the other variables. It is important to notice that the highest temperatures $\left(23-24^{\circ} \mathrm{C}\right)$ were recorded in the first day and then dropped to $20-21^{\circ} \mathrm{C}$ in the following days.

\section{Rice germination and growth}

As expected, no rice survived in the tank sides where crayfish was present, although the purpose of the experiment was not to quantify this effect. In the treatment tanks, the presence of crayfish in one side of the mesh changed the water quality but did not affect rice development in the opposite side. The Student's t test did not reveal statistically significant differences on seedlings height, total rice mass (dry weight), total mass of seeds (dry weight), and total mass of seedlings (fig. 3) (Table 2). The Mann-Whitney test did not find statistically significant differences on the number of seedlings, nor on the number of not germinated seeds (fig. 3, Table 2).

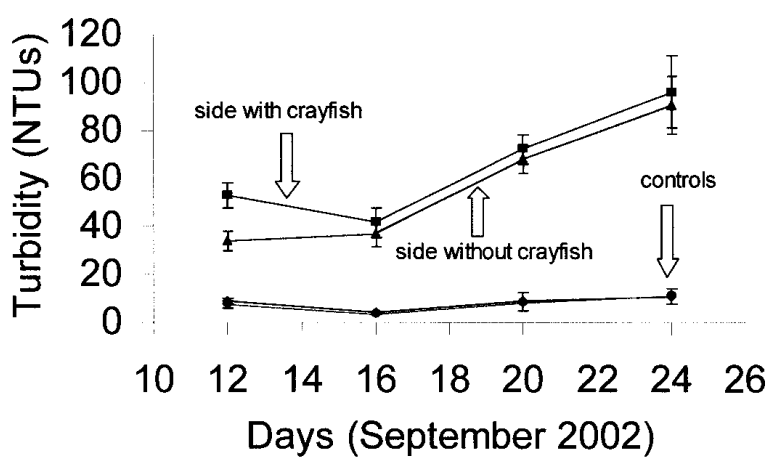

Fig. 2. Average values and standard errors of turbidity as affected by three different variables a) crayfish presence or absence in the tank b) side of the tank c) day of measurement.

\section{Discussion}

Crayfish may affect rice field water quality and this is demonstrated by this study. Turbidity increased and dissolved oxygen decreased when crayfish were added to tanks and it is possible that other unmonitored chemical modifications did occur. In spite of this, no effect on rice was observed when crayfish were present in the opposite side of the tank. This refutes the hypothesis by Anastácio \& Marques (1997) that some of the crayfish effects on rice would not be related to consumptive or non-consumptive destruction, but to changes in water quality, namely turbidity. Therefore at crayfish densities of 1.7 ind. $\mathrm{m}^{-2}$, which are typical of infested rice fields (Correia \& Bandeira 2005), water quality modifications caused by crayfish do not affect early stages of rice development.

Stevens \& Warren (2000), after 7 days experiments with oligochaete worms at low water depth, suggest that rice seedlings respond to high turbidity by partitioning more of their growth into shoot production. In our study, the bioturbation was caused by crayfish instead of oligochaete worms and turbidity was much lower i.e. less than 100 NTUs instead of a maximum of 500 NTUs. Moreover, at the end of our experiment,

Table 2. Results of the statistical analysis of the indirect effects of crayfish activity upon early stages of wet seeded rice growth. The effects of crayfish presence in the tank (although isolated by a mesh) or absence were compared.

\begin{tabular}{llc}
\hline Variable tested & Statistical Test & p \\
\hline Number of seedlings & Mann-Whitney U-test & 0.220 \\
Number of seeds & Mann-Whitney U-test & 0.462 \\
Average seedlings height & Student's t-test & 0.770 \\
Total rice mass & Student's t-test & 0.451 \\
Total seedling mass & Student's t-test & 0.456 \\
Total not germinated seeds mass & Student's t-test & 0.346 \\
\hline
\end{tabular}



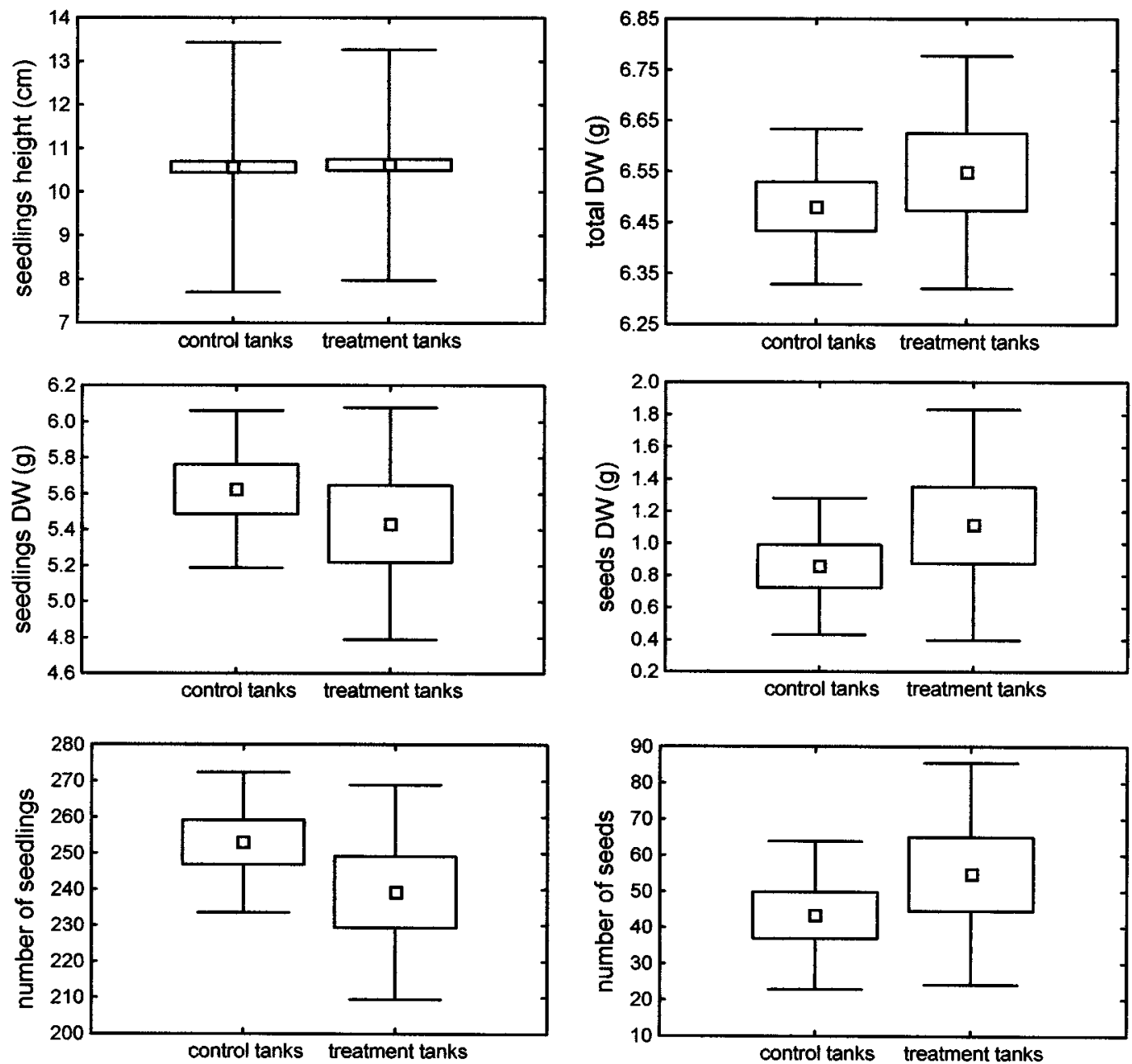

Fig. 3. Box and Whiskers plots of the values of several variables under two different treatment levels. Average, standard error and standard deviation are represented. control tanks $=$ tanks without crayfish. treatment tanks $=$ side without crayfish of the tanks with crayfish.

half of the plant was already out of the water and therefore was able to receive all the available solar radiation. These differences may justify the fact that no effects of turbidity on plant height are observed. Although working with carps in rice fields Vromant et al. (2001) obtained similar results regarding the effects of bioturbation upon water quality i.e. dissolved oxygen decreased and turbidity increased when carps where present. The increase in turbidity caused by carps has been described as a cause of impacts on macrophyte communities (Spence, Crowder \& Painter and Lauridsen et al. in Zambrano \& Hinojosa 1999). The impact on macrophytes may nevertheless be very low if the water is shallow (Zambrano \& Hinojosa 1999), which applies to the type of rice fields being simulated in our experiments.
Previous studies have highlighted the devastating impacts of crayfish on rice seeds and seedlings (Grigarick \& Way 1982, Anastácio \& Marques 1997 Anastácio et al. 2000), and among the direct effects, consumption is the most important factor (Parente 2002, Anastácio et al. 2005). None of these studies quantified the indirect effects via water quality. Although the studied indirect effects on rice seedlings were negligible, one cannot extend the conclusion to other stages of rice development. During germination rice plants rely on the seed contents for growth but later the effects of crayfish may be beneficial by the release of nutrients to the water column (Flint \& Goldman 1975, Bernardo \& Ilhéu 1994), consumption of rice competitors such as filamentous algae (Ilhéu \& Ber- 
nardo 1995, Barradas 2004) or reduction of rice pests such as chironomids (Bandeira 2002). It is well established by field experiments that direct crayfish impact on rice is negligible after the first weeks of growth (Anastácio \& Marques 1997). It remains nonetheless to be proven if during that period there is a strong indirect interaction between the two species.

\section{Acknowledgements}

This work was funded by «FCT - Fundação para a Ciência e Tecnologia », project POCTI/2001/BSE/42558 and by FEDER.

\section{References}

Anastácio P.M. \& Marques J.C. 1997. - Crayfish, Procambarus clarkii, effects on initial stages of rice growth in the lower Mondego River valley (Portugal). Freshwat. Crayfish, 11, 608-617.

Anastácio P.M., Correia A.M. \& Menino J.P. - 2005. Processes and patterns of plant destruction by crayfish : effects of crayfish size and development stages of rice. Arch. Hydrobiol, 162, 37-51.

Anastácio P.M., Frias A.F. \& Marques J.C. 2000. - Impact of crayfish densities on wet seeded rice and the inefficiency of a non-ionic surfactant as an Ecotechnological solution. Ecol. Eng., 15, 17-25.

Angeler D.G., Sanchez-Carrillo S., Garcia G. \& Alvarez-Cobelas M. 2001. - The influence of Procambarus clarkii (Cambaridae, Decapoda) on water quality and sediment characteristics in a Spanish floodplain wetland. Hydrobiologia, 464, 89-98.

Bellido L.L. 1991. - Cereales. Mundi-Prensa, Madrid, 539 p.

Bandeira N. 2002. - Effects of predation by Procambarus clarki (Crustacea, Decapoda) on macroinvertebrate prey. Bsc. Thesis, Departamento de Zoologia e Antropologia, Faculdade de Ciências, Universidade de Lisboa, 24 p.

Barradas, S.M. 2004. - Efeitos do Lagostim (Procambarus clarkii) sobre algas e infestantes dos arrozais. Bsc. Thesis, Departamento de Ecologia, Universidade de Évora, 65 p.

Bernardo J.M. \& Ilhéu M.A. 1994. - Red swamp crayfish (Procambarus clarkii) : Contribution to material cycling. Verh. Internat. Verein. Limnol., 25, 2447-2449.

Caffey R.H., Romaire R.P. \& Avault J.W. 1997. - Sustainable aquaculture : crawfish farming. Freshwat. Crayfish, 11, 587-598.

Caño E. \& Ocete M.E. 1994. - Estimación sobre las repercursiones socio-económicas de Procambarus clarkii Girard (Decapoda, Cambaridae) en las marismas del bajo Guadalquivir. Bol. San. Veg. Plagas, 20, 653-660.

Correia A.M. 1993. - Situation de l'acclimatation de l'écrevisse rouge des marais Procambarus clarkii au Portugal. Astacic. Fr., 35, 2-9.

Correia, A.M. \& Bandeira N. 2004. - Seasonal availability of Procambarus clarkii in the Tejo river basin, Portugal. Freshwat. Crayfish, 14, 190-196.

Dean J.L. 1969. - Biology of the crayfish Orconectes causeyi and its use for control of aquatic weeds in trout lakes. Tech. Papers, U.S. Bur. Sport. Fish. Wildl., 24, 1-15.

Flint R.W. \& Goldman C.R. 1975. - The effects of a benthic grazer on the primary productivity of the littoral zone of Lake Tahoe. Limnol. Oceanogr., 20, 935-944.

Fowler J. \& Cohen L. 1990. - Practical statistics for field biology. John Wiley \& Sons, New York, 227 p.

Grigarick A.A. 1984. - General problems with rice invertebrate pests and their control in the United States. Prot. Ecol., 7, 105-114.

Grigarick A.A. \& Way M.O. 1982. - Role of crayfish (decapoda : astacidae) as pests of rice in California and their control. J. Econ. Entomol., 75, 633-636.
Huner J.V. 1988. - Procambarus in North America and elsewhere. Pages 239-261 in Freshwater crayfish. Biology, management and exploitation. Holdich D.M. \& Lowery R.S. (eds.). Croom Helm, London.

Ilhéu M.A. \& Bernardo J.M. 1995. - Trophic ecology of red swamp crayfish Procambarus clarkii (Girard) - preferences and digestibility of plant foods. Freshwat. Crayfish, 10, 132-139.

Lowery R.S. \& Mendes A.J. 1977. - Procambarus clarkii in lake Naivasha, Kenya, and its effects on established and potential fisheries. Aquaculture, 11, 111-121.

McClain W.R., Neill W.H. \& Gatlin III D.M. 1992. - Nutrient profiles of green and decomposed rice-forages and their utilization by juvenile crayfish (Procambarus clarkii). Aquaculture, 101, 251-265.

Mead R., Curnow R.N. \& Hasted A.M. 2003. - Statistical methods in agriculture and experimental biology, Chapman \& Hall/CRC, Boca Raton, 472 p.

Parente V. 2002. - Mecanismos de destruição do arroz nos seus estadios iniciais de desenvolvimento por parte do lagostim-Vermelhoda-Luisiana (Procambarus clarkii). Bsc. Thesis, Departamento de Ecologia, Universidade de Évora, Portugal, 74 p.

Poovey A.G. \& Getsinger K.D. 2002. - Impacts of inorganic turbidity on diquat efficacy against Egeria densa. J. Aquat. Plant Manag., 40, 6-10.

Ricket J.D. 1974. - Trophic relationships involving crayfish of the genus Orconectes in experimental ponds. Prog. Fish-cult., 36, 207-211.

Rodríguez C.L., Bécares E. \& Fernández-Aláez M. 2003. - Shift from clear to turbid phase in Lake Chozas (NW Spain) due to the introduction of American red swamp crayfish (Procambarus clarkii). Hydrobiologia, 506-509, 421-426.

Sanguaruang M. 1988. - Bioenergetics of red swamp crayfish (Procambarus clarkii) and white river crayfish (Procambarus acutus acutus) in cultivated, noncultivated and wooded ponds in south Louisiana. PhD. Thesis. The Louisiana State University and Agricultural and Mechanical Coll. The School of Forestry, Wildlife and Fisheries, $131 \mathrm{p}$.

Sommer T.R. \& Goldman C.R. 1983. - The crayfish Procambarus clarkii from California ricefields. Ecology, problems and potential harvest. Freshwat. Crayfish, 5, 418-428.

Stevens M.M. \& Warren G.N. 2000. - Laboratory studies on the influence of the earthworm Eukerria saltensis (Beddard) (Oligochaeta : Ocnerodrilidae) on overlying water quality and rice plant establishment. Int. J. Pest Manag., 46, 303-310.

Takahashi N. 1984. - Seed germination and seedling growth. Pages 71-78 in Biology of rice. Tsunoda S. \& Takahashi N. (eds.). Japan Sci. Soc. Press / Elsevier, Tokyo.

Tinarelli A. 1989. - El Arroz. Ediciones Mundi-Prensa, Madrid, 575 p.

Usio N. 2000. - Effects of crayfish on leaf processing and invertebrate colonisation of leaves in a headwater stream : Decoupling of a trophic cascade. Oecologia, 124, 608-614.

Usio N. \& Townsend C.R. 2002. - Functional significance of crayfish in stream food webs : role of omnivory, substrate heterogeneity and sex. Oikos, 98, 512-522.

Vromant N., Chau N.T.H. \& Ollevier F. 2001. - The effect of riceseeding rate and fish stocking on the floodwater ecology of the trench of a concurrent, direct-seeded rice-fish system. Hydrobiologia, 457, 105-117.

Zambrano L. \& Hinojosa D. 1999. - Direct and indirect effects of carp (Cyprinus carpio L.) on macrophyte and benthic communities in experimental shallow ponds in central Mexico. Hydrobiologia, 409, 131-138. 